\title{
Kocuria flava sp. nov. and Kocuria turfanensis sp. nov., airborne actinobacteria isolated from Xinjiang, China
}

\author{
Correspondence \\ Chengxiang Fang \\ cxfang@whu.edu.cn
}

\author{
Guoling Zhou, $†$ Xuesong Luo, † Yali Tang, Lei Zhang, Qiao Yang, \\ Yijun Qiu and Chengxiang Fang
}

\author{
China Centre for Type Culture Collection (CCTCC), College of Life Sciences, Wuhan University, \\ Wuhan 430072, PR China
}

\begin{abstract}
Two coloured bacteria were isolated from the same plate for detecting cultivable bacteria from the air of Xinjiang in China. Phylogenetic analyses based on 16S rRNA gene sequences revealed that the isolates were members of the genus Kocuria, in which they represented two novel lineages. Although the two strains presented high 16S rRNA gene sequence similarity (above $97 \%$ ), their DNA G $+\mathrm{C}$ contents were very different (6 mol\%). The $\mathrm{G}+\mathrm{C}$ contents of strains $\mathrm{HO}$ $9041^{\top}$ and $\mathrm{HO}-9042^{\top}$ are 71 and $65 \mathrm{~mol} \%$, respectively. DNA relatedness analysis and other taxonomic evidence supports the placement of the two isolates in the genus Kocuria. The diagnostic diamino acid of the cell-wall peptidoglycan is L-lysine and both strains contain MK$8\left(\mathrm{H}_{2}\right)$ and MK-9 $\left(\mathrm{H}_{2}\right)$ as major menaquinones. In addition, they share similar fatty acid patterns containing straight-chain saturated and iso- and anteiso-branched acids, with a major component being anteiso- $\mathrm{C}_{15: 0}$. Genotypic, morphological and physiological characteristics are used to describe two novel species of Kocuria, for which the names Kocuria flava sp. nov. (type strain $\mathrm{HO}-9041^{\top}=\mathrm{CCTCC} \mathrm{AB} 206106^{\top}=\mathrm{KCTC} 19306^{\top}$ ) and Kocuria turfanensis sp. nov. (type strain $\mathrm{HO}-9042^{\top}=$ CCTCC AB $206107^{\top}=$ KCTC $19307^{\top}$ ) are proposed.
\end{abstract}

At the time of writing, the genus Kocuria Stackebrandt et al. 1995 contains 11 species with validly published names: Kocuria rosea (the type species), K. varians, K. kristinae (Stackebrandt et al., 1995), K. erythromyxa (Rainey et al., 1997; regarded as a later synonym of $K$. rosea by Schumann et al., 1999), K. palustris, K. rhizophila (Kovács et al., 1999), K. polaris (Reddy et al., 2003), K. marina (Kim et al., 2004), K. carniphila (Tvrzová et al., 2005), K. aegyptia (Li et al., 2006) and K. himachalensis (Mayilraj et al., 2006). These species were recovered from such varied environments as a saline, alkaline desert ( $K$. aegyptia), meat ( . carniphila), marine sediment ( $K$. marina), the rhizoplane of narrowleaved cattail (K. palustris, K. rhizophila) and an Antarctic cyanobacterial mat sample (K. polaris). The members of this genus are Gram-positive, aerobic, coccoid, nonencapsulated, non-halophilic and non-endospore-forming, with the presence of the fatty acid anteiso- $\mathrm{C}_{15: 0}$ and MK$7\left(\mathrm{H}_{2}\right)$ and MK- $8\left(\mathrm{H}_{2}\right)$ as the major menaquinones. In the

†These authors contributed equally to this work.

The GenBank/EMBL/DDBJ accession numbers for the 16S rRNA gene sequences of strains $\mathrm{HO}-9041^{\top}$ and $\mathrm{HO}-9042^{\top}$ are EF602041 and D0531634.

Detailed fatty acid profiles of the novel strains and related type strains are available as supplementary material with the online version of this paper. present study, strains $\mathrm{HO}-9041^{\mathrm{T}}$ and $\mathrm{HO}-9042^{\mathrm{T}}$ were identified as members of novel species of the genus Kocuria on the basis of a polyphasic taxonomy study.

The two strains were isolated from a TGYA plate containing $\left(1^{-1}\right) 5.0 \mathrm{~g}$ tryptone, $3.0 \mathrm{~g}$ yeast extract, $1.0 \mathrm{~g}$ glucose and $16.0 \mathrm{~g}$ agar. Colonies of the two strains were different; colonies of HO-9041 ${ }^{\mathrm{T}}$ were yellow, whereas $\mathrm{HO}-9042^{\mathrm{T}}$ formed orange (after $48 \mathrm{~h}$ on TGYA plates) to red (after 4 days) colonies.

Isolation of genomic DNA of the two strains was carried out according to the method described by Yoon et al. (1996). Fragments comprising nearly the full-length $16 \mathrm{~S}$ rRNA gene were amplified by a PCR using primers described by Rainey et al. (1996). The PCR products were then sequenced by the Invitrogen Corporation. Phylogenetic analysis revealed that both strains were closely related to the type strains of $K$. rosea, $K$. polaris and $K$. aegyptia (Fig. 1), with 16S rRNA gene similarities higher than $97 \%$ (sequence similarity calculated by NCBI align two sequences and listed in Table 1). Multiple alignments with sequences of the most closely related actinobacteria were carried out using CLUSTAL_X (Thompson et al., 1997). Phylogenetic trees were constructed using the neighbourjoining method (Fig. 1) and maximum-parsimony method by using MEGA version 3.1 (Kumar et al., 2004). The 


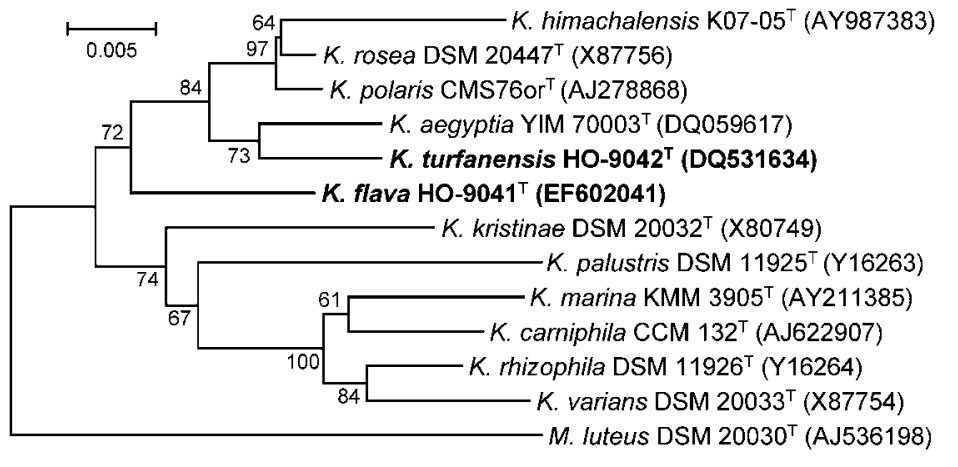

Fig. 1. Neighbour-joining tree (Saitou \& Nei, 1987) based on 16S rRNA gene sequences, showing the phylogenetic relationship between strains $\mathrm{HO}-9041^{\top}$ and $\mathrm{HO}-9042^{\top}$ and other members of the genus Kocuria. Micrococcus luteus DSM $20030^{\top}$ (Wieser et al., 2002) was used as an outgroup. Bootstrap values (expressed as percentages of 1000 replications) greater than $50 \%$ are given at nodes. Bar, $0.5 \%$ sequence variation. topology of the phylogenetic tree by the neighbour-joining method was evaluated by using the bootstrap resampling method of Felsenstein (1985) with 1000 replicates.

The DNA G $+\mathrm{C}$ contents were $71 \mathrm{~mol} \%\left(\mathrm{HO}-9041^{\mathrm{T}}\right)$ and $65 \mathrm{~mol} \%\left(\mathrm{HO}-9042^{\mathrm{T}}\right)$ as determined by the HPLC method (Kumagai et al., 1988). DNA-DNA hybridizations were carried out with photobiotin-labelled probes in microplate wells as described by Ezaki et al. (1989). All of the determined DNA-DNA hybridization values were less than 70 \% (Table 1) (Stackebrandt \& Goebel, 1994).

Morphological analyses were performed by using a standardized method (Murray et al., 1994). Physiological tests, such as growth at different temperatures $(5,10,28$, 30,42 and $\left.45{ }^{\circ} \mathrm{C}\right), \mathrm{pH}(5.5,6,7,8,9,9.5,10,10.5,11,11.5$ and 12) and $\mathrm{NaCl}$ concentrations $(1,3,5,8,10,15$ and $17 \%$ ), were performed by growing the strains in TGY broth under appropriate test conditions. Catalase activity, indole production, the methyl red and Voges-Proskauer

Table 1. 16S rRNA gene sequence similarity and DNA-DNA hybridization results

Values are percentages of 16S rRNA gene sequence similarity/DNADNA relatedness. 16S rRNA gene sequences of reference type strains were obtained from previous studies and some reference strains for hybridization were obtained from the DSMZ and CCTCC. ND, Not determined.

\begin{tabular}{|c|c|c|}
\hline Strain & HO-9041 ${ }^{\mathrm{T}}$ & HO-9042 ${ }^{\mathrm{T}}$ \\
\hline Strain HO- $9041^{\mathrm{T}}$ & $(100) /(100)$ & - \\
\hline Strain HO- $9042^{\mathrm{T}}$ & $97.9 / 35.2$ & $(100) /(100)$ \\
\hline K. rosea DSM $20447^{\mathrm{T}}$ & $97.8 / 58.3$ & $98.2 / 34.5$ \\
\hline K. polaris MTCC $3702^{\mathrm{T}}$ & $97.6 / 45.3$ & $98.1 / 52.9$ \\
\hline K. aegyptia YIM $70003^{\mathrm{T}}$ & $97.1 / 60.8$ & $98.3 / 53.8$ \\
\hline K. palustris DSM $11925^{\mathrm{T}}$ & $96.8 / \mathrm{ND}$ & $96.5 / \mathrm{ND}$ \\
\hline K. himachalensis DSM $44905^{\mathrm{T}}$ & $96.5 / \mathrm{ND}$ & $96.8 / \mathrm{ND}$ \\
\hline K. carniphila CCM $132^{\mathrm{T}}$ & $96.6 / \mathrm{ND}$ & $96.7 / \mathrm{ND}$ \\
\hline K. marina $\mathrm{KMM} 3905^{\mathrm{T}}$ & $96.2 / \mathrm{ND}$ & $96.5 / \mathrm{ND}$ \\
\hline K. rhizophila DSM $11926^{\mathrm{T}}$ & $96.2 / \mathrm{ND}$ & $96.5 / \mathrm{ND}$ \\
\hline K. varians DSM $20033^{\mathrm{T}}$ & $96.5 / \mathrm{ND}$ & $96.1 / \mathrm{ND}$ \\
\hline K. kristinae DSM $20032^{\mathrm{T}}$ & $95.4 / \mathrm{ND}$ & $95.8 / \mathrm{ND}$ \\
\hline
\end{tabular}

tests, oxidase and gelatinase activities, starch hydrolysis (amylase), nitrate reduction and urease, phosphatase, $\beta$ galactosidase and $\beta$-glucuronidase activities were assessed as described by Smibert \& Krieg (1994) (Table 2). Low concentrations $\left(20 \mu \mathrm{g} \mathrm{ml}^{-1}\right)$ of antibiotics were used to detect resistance of the strains; both strains were sensitive to kanamycin, ampicillin, carbenicillin, chlortetracycline and erythromycin.

The utilization of various carbon compounds as sole carbon sources was tested using Biolog GP2 MicroPlates in accordance with the manufacturer's instructions with no adjustments. Strains were cultivated on BUG agar (Biolog catalogue no. 71101 ) with $5 \%$ sheep blood at $30{ }^{\circ} \mathrm{C}$ for $24-$ $48 \mathrm{~h}$. Inoculated plates were incubated for $24 \mathrm{~h}$ and the results were read with a MicroPlate Reader using the Microlog 4.2 computer software to perform automated readings. Some results are listed in Table 2, and the others are shown in the species description

A cell wall hydrolysate was prepared by the method of Komagata \& Suzuki (1987). The peptidoglycan of both strains contained L-lysine as the diagnostic diamino acid, as analysed by two-dimensional TLC on cellulose plates using the solvent systems of Schleifer \& Kandler (1972). In addition, extraction of menaquinones and determination of menaquinone profiles by HPLC was done as described previously (Xie \& Yokota, 2003). Strain HO-9041 ${ }^{\mathrm{T}}$ contained MK-8 $\left(\mathrm{H}_{2}\right)(69 \%)$, MK-9 $\left(\mathrm{H}_{2}\right)(18 \%)$ and MK$7\left(\mathrm{H}_{2}\right)(13 \%)$ and $\mathrm{HO}-9042^{\mathrm{T}}$ possessed $\mathrm{MK}-8\left(\mathrm{H}_{2}\right)(46 \%)$, MK-9 $\left(\mathrm{H}_{2}\right)(31 \%)$ and MK-7 $\left(\mathrm{H}_{2}\right)(27 \%)$.

For cellular fatty acid analysis, the strains were grown on TSA at $30{ }^{\circ} \mathrm{C}$ for $24 \mathrm{~h}$ and cellular fatty acids were extracted, methylated and analysed by using the Sherlock Microbial Identification System (MIDI) according to the manufacturer as described previously (Pandey et al., 2002); detailed fatty acid profiles are given in Supplementary Table S1, available in IJSEM Online.

Based on the results of phylogenetic analysis and other properties, strains $\mathrm{HO}-9041^{\mathrm{T}}$ and $\mathrm{HO}-9042^{\mathrm{T}}$ are proposed as the type strains of two novel Kocuria species, respectively named Kocuria flava sp. nov. and Kocuria turfanensis sp. nov. 
Table 2. Differential physiological characteristics of strains $\mathrm{HO}-9041^{\top}$ and $\mathrm{HO}-9042^{\top}$ and type strains of closely related species

Strains: 1 , HO-9041 ${ }^{\mathrm{T}} ; 2, \mathrm{HO}-9042^{\mathrm{T}} ; 3$, K. rosea DSM $20447^{\mathrm{T}} ; 4, \mathrm{~K}$. polaris MTCC $3702^{\mathrm{T}} ; 5, K$. aegyptia YIM $70003^{\mathrm{T}}$. All data are from the present study. +, Positive; - , negative; $\mathrm{w}$, weakly positive. All strains were negative for gelatinase, indole production and the methyl red and Voges-Proskauer tests and positive for catalase. In Biolog GP2 tests, all strains were positive for the utilization of dextrin, glycogen, Tweens 40 and 80 , D-fructose, $\alpha$-D-glucose, maltose, maltotriose, D-mannose, Dpsicose, D-ribose, D-sorbitol, sucrose, turanose, D-xylose, acetic acid, $\alpha$-, $\beta$ - and $\gamma$-hydroxybutyric acids, $\alpha$-ketovaleric acid, D-lactic acid methyl ester, L-lactic acid, L-malic acid, succinic acid monomethyl ester, pyruvic acid, glycerol, adenosine, thymidine and uridine and negative for mannan, $N$-acetyl-D-glucosamine, D-arabitol, L-fucose, methyl $\beta$-Dgalactoside, methyl $\alpha$-D-mannoside, salicin, sedoheptulosan, glycyl Lglutamic acid and thymidine $5^{\prime}$-monophosphate.

\begin{tabular}{|c|c|c|c|c|c|}
\hline Characteristic & 1 & 2 & 3 & 4 & 5 \\
\hline Colony colour ${ }^{\star}$ & Y & $\mathrm{O}-\mathrm{R}$ & $\mathrm{O}-\mathrm{R}$ & $\mathrm{O}$ & $\mathrm{O}-\mathrm{P}$ \\
\hline \multicolumn{6}{|l|}{ Ranges for growth } \\
\hline $\mathrm{NaCl}(\%)$ & $0-10$ & $0-15$ & $0-5$ & $0-1$ & $1-5$ \\
\hline Temperature $\left({ }^{\circ} \mathrm{C}\right)$ & $30-45$ & $30-40$ & $30-37$ & $5-28$ & $30-37$ \\
\hline $\mathrm{pH}$ & $7-9$ & $6-9.5$ & $6-9$ & $7-12$ & $5.5-11$ \\
\hline Nitrate reduction & + & $\mathrm{W}$ & + & + & - \\
\hline Urease & + & - & - & - & - \\
\hline Oxidase & - & - & + & + & - \\
\hline Phosphatase & + & + & - & - & w \\
\hline$\beta$-Galactosidase & $\mathrm{W}$ & + & - & - & - \\
\hline Amylase & + & + & - & + & - \\
\hline \multicolumn{6}{|l|}{ Carbon-source utilization } \\
\hline$\alpha$-Cyclodextrin & + & + & - & - & - \\
\hline L-Arabinose & + & - & $\mathrm{W}$ & + & - \\
\hline D-Gluconic acid & + & - & $\mathrm{w}$ & - & - \\
\hline $\begin{array}{l}\text { Pyruvic acid methyl } \\
\text { ester }\end{array}$ & - & + & - & - & + \\
\hline Methyl $\beta$-D-glucoside & + & - & - & - & - \\
\hline $\begin{array}{l}N \text {-Acetyl-L-glutamic } \\
\text { acid }\end{array}$ & - & + & $\mathrm{W}$ & $\mathrm{W}$ & - \\
\hline$\alpha$-Ketoglutaric acid & + & - & + & + & + \\
\hline$\alpha$-D-Lactose & + & - & + & $\mathrm{w}$ & - \\
\hline Inulin & + & - & $\mathrm{W}$ & - & - \\
\hline $\begin{array}{l}p \text {-Hydroxyphenylacetic } \\
\text { acid }\end{array}$ & + & + & - & - & - \\
\hline $\begin{array}{l}\text { DNA G }+C \text { content } \\
(\mathrm{mol} \%)\end{array}$ & 71 & 65 & 70.2 & 72.3 & 73 \\
\hline
\end{tabular}

${ }^{*} \mathrm{O}$, Orange; P, pink; R, red; $\mathrm{Y}$, yellow.

\section{Description of Kocuria flava sp. nov.}

Kocuria flava (fla'va. L. fem. adj. flava yellow, referring to the colony colour of the type strain).

Gram-positive, aerobic, non-motile and coccoid cells. Positive for catalase, nitrate reduction, amylase, phosphatase and urease, but negative for oxidase, gelatinase and $\beta$-glucuronidase. Production of indole and acetoin (Voges-
Proskauer reaction) is negative. Growth can occur in the absence of $\mathrm{NaCl}$ and in the presence of up to $10 \% \mathrm{NaCl}$, at $28-45{ }^{\circ} \mathrm{C}$ and $\mathrm{pH} 7-9$. Substrates utilized as sole carbon sources are given in Table 2 . In addition, $\beta$-cyclodextrin, D-galactose, myo-inositol, D-mannitol, melibiose, methyl $\alpha$ D-galactoside, palatinose, raffinose, stachyose, D-tagatose, trehalose, D-malic acid, propionic acid, succinamic acid, succinic acid, L-alaninamide, L-alanyl glycine, L-asparagine, L-glutamic acid, L-pyroglutamic acid, L-serine, putrescine, 2,3-butanediol, 2'-deoxyadenosine, inosine, adenosine $5 '$-monophosphate, D-fructose 6-phosphate, $\alpha$-D-glucose 1-phosphate, D-glucose 6-phosphate and DL- $\alpha$-glycerol phosphate can be utilized, whereas $N$-acetyl-D-glucosamine, amygdalin, arbutin, cellobiose, D-galacturonic acid, gentiobiose, lactulose, 3-methyl D-glucose, lactamide, alanine and uridine 5'-monophosphate are not utilized. The type strain is sensitive to kanamycin, ampicillin, carbenicillin, chlortetracycline and erythromycin. Contains the major cellular fatty acid 15:0 anteiso and the predominant quinones MK- $8\left(\mathrm{H}_{2}\right)$ and MK-9 $\left(\mathrm{H}_{2}\right)$ and contains L-lysine as the diagnostic diamino acid. The $\mathrm{G}+\mathrm{C}$ content of the genomic DNA of the type strain is $71 \mathrm{~mol} \%$.

The type strain is HO-9041 ${ }^{\mathrm{T}}$ (=CCTCC AB $206106^{\mathrm{T}}$ $=$ KCTC $19306^{\mathrm{T}}$ ), isolated from the air.

\section{Description of Kocuria turfanensis sp. nov.}

Kocuria turfanensis (tur.fan.en'sis. N.L. fem. adj. turfanensis referring to Turfan, China, the geographical origin of the type strain).

Gram-positive, aerobic, non-motile and coccoid cells. Positive for catalase, nitrate reduction, amylase, phosphatase and $\beta$-galactosidase, but negative for oxidase, gelatinase, urease, $\beta$-glucuronidase and urease. Production of indole and acetoin (Voges-Proskauer reaction) is negative. Growth can occur in $15 \% \mathrm{NaCl}$; however, $\mathrm{NaCl}$ is not necessary for growth. Growth is also detected at $30-40{ }^{\circ} \mathrm{C}$ and $\mathrm{pH}$ 6.5-9. Substrates utilized as sole carbon sources are given in Table 2 . In addition, $\beta$-cyclodextrin, D-galactose, myo-inositol, D-mannitol, melibiose, methyl $\alpha$-D-galactoside, palatinose, raffinose, trehalose, 2'-deoxyadenosine and inosine are also utilized. Other substrates in the Biolog GP2 plate are not utilized. The type strain is sensitive to kanamycin, ampicillin, carbenicillin, chlortetracycline and erythromycin. Contains the major cellular fatty acids $15: 0$ anteiso and 15:0 iso and the predominant menaquinones MK- $8\left(\mathrm{H}_{2}\right)$ and MK-9 $\left(\mathrm{H}_{2}\right)$ and contains L-lysine as the diagnostic diamino acid. The $\mathrm{G}+\mathrm{C}$ content of the genomic DNA of the type strain is $65 \mathrm{~mol} \%$.

The type strain is $\mathrm{HO}-9042^{\mathrm{T}}$ (=CCTCC AB $206107^{\mathrm{T}}$ $=$ KCTC $19307^{\mathrm{T}}$ ), isolated from the air.

\section{Acknowledgements}

This work was supported by the National Infrastructure of Natural Resources for Science and Technology program, Ministry of Science and Technology, People's Republic of China. We also thank Huahong 
Chen (Laboratory for Conservation and Utilization of Bio-Resources, Yunnan Institute of Microbiology, Yunnan University) for performing DNA hybridization experiments, Dr Akira Yokota (Institute of Molecular and Cellular Biosciences, University of Tokyo) for performing quinone analysis and Mengxi Wang (College of Life Sciences, Wuhan University) for helpful suggestions.

\section{References}

Ezaki, T., Hashimoto, Y. \& Yabuuchi, E. (1989). Fluorometric deoxyribonucleic acid-deoxyribonucleic acid hybridization in microdilution wells as an alternative to membrane filter hybridization in which radioisotopes are used to determine genetic relatedness among bacterial strains. Int J Syst Bacteriol 39, 224-229.

Felsenstein, J. (1985). Confidence limits on phylogenies: an approach using the bootstrap. Evolution 39, 783-791.

Kim, S. B., Nedashkovskaya, O. I., Mikhailov, V. V., Han, S. K., Kim, K.-O., Rhee, M. S. \& Bae, K. S. (2004). Kocuria marina sp. nov., a novel actinobacterium isolated from marine sediment. Int J Syst Evol Microbiol 54, 1617-1620.

Komagata, K. \& Suzuki, K. (1987). Lipid and cell-wall analysis in bacterial systematics. Methods Microbiol 19, 161-207.

Kovács, G., Burghardt, J., Pradella, S., Schumann, P., Stackebrandt, E. \& Màrialigetti, K. (1999). Kocuria palustris sp. nov. and Kocuria rhizophila sp. nov., isolated from the rhizoplane of the narrow-leaved cattail (Typha angustifolia). Int J Syst Bacteriol 49, 167-173.

Kumagai, M., Fujimoto, M. \& Kuninaka, A. (1988). Determination of base composition of DNA by high performance liquid chromatography of its nuclease P1 hydrolysate. Nucleic Acids Symp Ser 19, 65-68.

Kumar, S., Tamura, K. \& Nei, M. (2004). MEGA3: integrated software for molecular evolutionary genetics analysis and sequence alignment. Brief Bioinform 5, 150-163.

Li, W.-J., Zhang, Y.-Q., Schumann, P., Chen, H.-H., Hozzein, W. N., Tian, X.-P., Xu, L.-H. \& Jiang, C.-L. (2006). Kocuria aegyptia sp. nov., a novel actinobacterium isolated from a saline, alkaline desert soil in Egypt. Int J Syst Evol Microbiol 56, 733-737.

Mayilraj, S., Kroppenstedt, R. M., Suresh, K. \& Saini, H. S. (2006). Kocuria himachalensis sp. nov., an actinobacterium isolated from the Indian Himalayas. Int J Syst Evol Microbiol 56, 1971-1975.

Murray, R. G. E., Doetsch, R. N. \& Robinow, F. (1994). Determinative and cytological light microscopy. In Methods for General and Molecular Bacteriology, pp. 21-41. Edited by P. Gerhardt, R. G. E. Murray, W. A. Wood \& N. R. Krieg. Washington, DC: American Society for Microbiology.

Pandey, K. K., Mayilraj, S. \& Chakrabarti, T. (2002). Pseudomonas indica sp. nov., a novel butane-utilizing species. Int J Syst Evol Microbiol 52, 1559-1567.

Rainey, F. A., Ward-Rainey, N., Kroppenstedt, R. M. \& Stackebrandt, E. (1996). The genus Nocardiopsis represents a phylogenetically coherent taxon and a distinct actinomycete lineage: proposal of Nocardiopsiaceae fam. nov. Int J Syst Bacteriol 46, 1088-1092.
Rainey, F. A., Nobre, M. F., Schumann, P., Stackebrandt, E. \& Da Costa, M. S. (1997). Phylogenetic diversity of the deinococci as determined by $16 \mathrm{~S}$ ribosomal DNA sequence comparison. Int J Syst Bacteriol 47, 510-514.

Reddy, G. S. N., Prakash, J. S. S., Prabahar, V., Matsumoto, G. I., Stackebrandt, E. \& Shivaji, S. (2003). Kocuria polaris sp. nov., an orange-pigmented psychrophilic bacterium isolated from an Antarctic cyanobacterial mat sample. Int J Syst Evol Microbiol 53, 183-187.

Saitou, N. \& Nei, M. (1987). The neighbor-joining method: a new method for reconstructing phylogenetic trees. Mol Biol Evol 4, 406-425.

Schleifer, K. H. \& Kandler, O. (1972). Peptidoglycan types of bacterial cell walls and their taxonomic implications. Bacteriol Rev 36, 407-477.

Schumann, P., Spröer, C., Burghardt, J., Kovacs, G. \& Stackebrandt, E. (1999). Reclassification of the species Kocuria erythromyxa (Brooks and Murray 1981) as Kocuria rosea (Flügge 1886). Int J Syst Bacteriol 49, 393-396.

Smibert, R. M. \& Krieg, N. R. (1994). Phenotypic characterization. In Methods for General and Molecular Bacteriology, pp. 607-654. Edited by P. Gerhardt, R. G. E. Murray, W. A. Wood \& N. R. Krieg. Washington, DC: American Society for Microbiology.

Stackebrandt, E. \& Goebel, B. M. (1994). Taxonomic note: a place for DNA-DNA reassociation and $16 \mathrm{~S}$ rRNA sequence analysis in the present species definition in bacteriology. Int J Syst Bacteriol 44, 846-849.

Stackebrandt, E., Koch, C., Gvozdiak, O. \& Schumann, P. (1995). Taxonomic dissection of the genus Micrococcus: Kocuria gen. nov., Nesterenkonia gen. nov., Kytococcus gen. nov., Dermacoccus gen. nov., and Micrococcus Cohn 1872 gen. emend. Int J Syst Bacteriol 45, 682-692.

Thompson, J. D., Gibson, T. J., Plewniak, F., Jeanmougin, F. \& Higgins, D. G. (1997). The CLUSTAL_X windows interface: flexible strategies for multiple sequence alignment aided by quality analysis tools. Nucleic Acids Res 25, 4876-4882.

Tvrzová, L., Schumann, P., Sedláček, I., Páčová, Z., Spröer, C., Verbarg, S. \& Kroppenstedt, R. M. (2005). Reclassification of strain CCM 132, previously classified as Kocuria varians, as Kocuria carniphila sp. nov. Int J Syst Evol Microbiol 55, 139-142.

Wieser, M., Denner, E. B. M., Kämpfer, P., Schumann, P., Tindall, B., Steiner, U., Vybiral, D., Lubitz, W., Maszenan, A. M. \& other authors (2002). Emended descriptions of the genus Micrococcus, Micrococcus luteus (Cohn 1872) and Micrococcus lylae (Kloos et al. 1974). Int J Syst Evol Microbiol 52, 629-637.

Xie, C. H. \& Yokota, A. (2003). Phylogenetic analyses of Lampropedia hyalina based on the 16S rRNA gene sequence. J Gen Appl Microbiol 49, 345-349.

Yoon, J.-H., Kim, H., Kim, S.-B., Kim, H.-J., Kim, W. Y., Lee, S. T., Goodfellow, M. \& Park, Y.-H. (1996). Identification of Saccharomonospora strains by the use of genomic DNA fragments and rRNA gene probes. Int J Syst Bacteriol 46, 502-505. 